\title{
Value of ultrasonographic optic nerve sheath diameter in assessing increased intracranial pressure in patients with moderate to severe traumatic brain injury
}

\author{
A Abdalla ${ }^{1 *}$, BN Beshey ${ }^{1}$, AM Abougabal ${ }^{2}$, KM Elzahaby $^{3}$ \\ From ESICM LIVES 2015 \\ Berlin, Germany. 3-7 October 2015
}

\section{Introduction}

Among the factors associated with long-term outcome after TBI, intracranial pressure (ICP) confirms its relevance. Of the non-invasive methods to assess raised ICP, ultrasound measures of optic nerve diameter seems especially promising and can be used in selected situations.

\section{Objectives}

To determine the value of optic nerve sheath diameter measurement using ultrasonography in assessing increased intracranial pressure and outcome of moderate to severe traumatic brain injury patients.

\section{Methods}

We enrolled 40 patients admitted over a period of 6 months with moderate to severe traumatic brain injury to the Department of Critical Care Medicine at the Alexandria Main University Hospital. ONSD measurements were performed by means of transorbital sonography daily for 7 days. Marshall and Rotterdam head CT neuroimaging scales were recorded on admission, 48 hours and 5 to 7 days later. Glasgow Outcome Scale (GOS) was assessed six months after discharge for survivors.

\section{Results}

The mean ONSD upon admission (baseline value) was $6.29 \pm 0.78 \mathrm{~mm}$, increasing non-significantly on day 2 to $6.53 \pm 0.53 \mathrm{~mm}(\mathrm{p}=0.546)$. However, on days 3,4 , and 5 the mean ONSD significantly increased to $6.63 \pm 0.57 \mathrm{~mm}$ $(\mathrm{p}=0.030), 6.72 \pm 0.65 \mathrm{~mm}(\mathrm{p}=0.001)$, and $6.70 \pm$ $0.71 \mathrm{~mm}(\mathrm{p}=0.003)$ respectively compared to the baseline value. A non-significant increase followed in days 6 and 7 to means of $6.59 \pm 0.73 \mathrm{~mm}(\mathrm{p}=0.249)$, and $6.38 \pm$ $0.72 \mathrm{~mm}(\mathrm{p}=1.000)$ respectively compared to the baseline value. The serial comparison of each mean ONSD to either the preceding or following daily mean was significant $(\mathrm{p}<0.001)$. We couldn't demonstrate any correlation between ONSD and either of the neuroimaging scales used to evaluate intracranial hypertension; namely, Marshall Scale and Rotterdam Scale. ONSD could not predict mortality in our TBI patients.

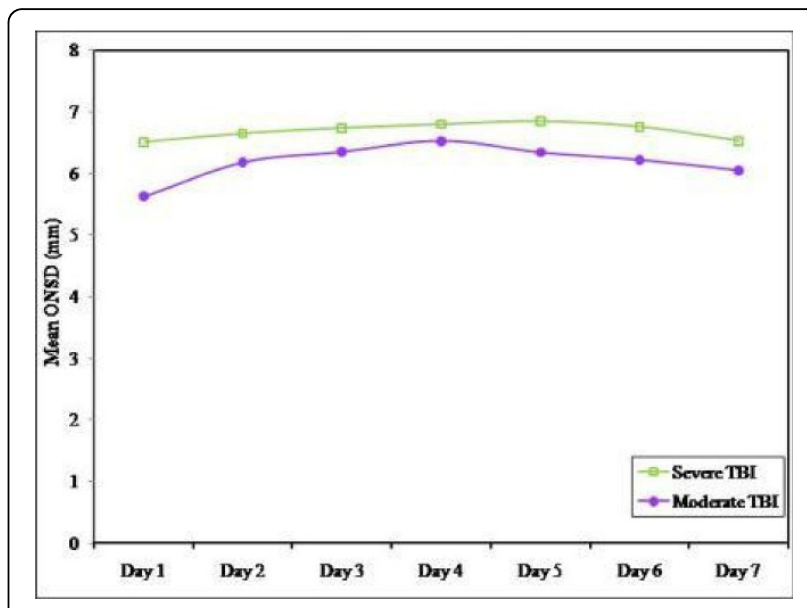

Figure 1 Comparison of the mean ONSD of the studied cases over the period of seven days. 


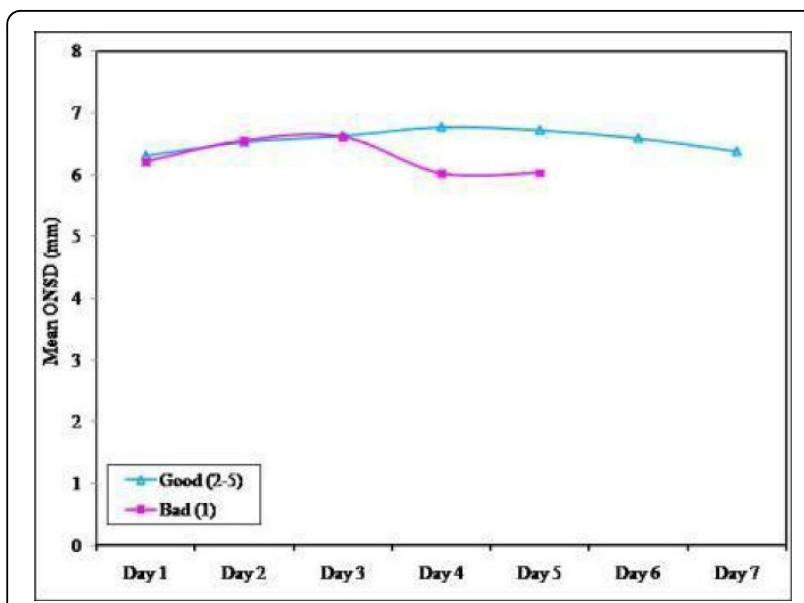

Figure 2 Mean ONSD comparison of the studied cases over the period of seven days.

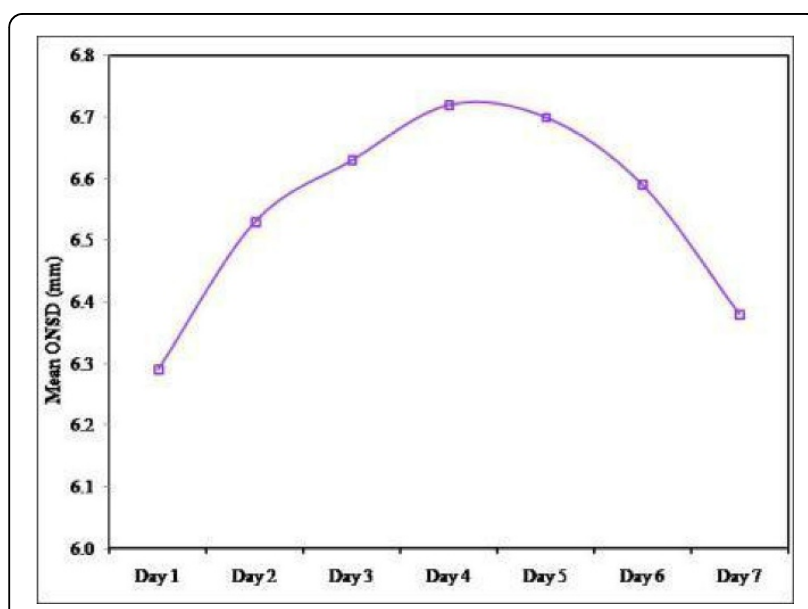

Figure 3 Mean ONSD of the studied cases over the period of 7 days.

\section{Conclusions}

In the early posttraumatic period, transorbital ultrasound scans to measure ONSD may be useful for detecting high ICP after moderate severe TBI by providing additional non-invasive means of assessing ICP. However it doesnot predict mortality in the severe TBI patients.

\section{Authors' details}

${ }^{1}$ Alexandria University, Faculty of Medicine, Critical Care, Alexandria, Egypt.

${ }^{2}$ Alexandria University, Faculty of Medicine, Radiodiagnosis, Alexandria, Egypt.

${ }^{3}$ Police Force Hospital, Intensive Care, Alexandria, Egypt.

Published: 1 October 2015

\section{References}

1. Geeraerts T, Merceron S, Benhamou D, Vigué B, Duranteau J: Non-invasive assessment of intracranial pressure using ocular sonography in neurocritical care patients. Intensive Care Med 2008, 34(11):2062-2067.
2. Tayal VS, Neulander M, Norton HJ, Foster T, Saunders T, Blaivas M: Emergency department sonographic measurement of optic nerve sheath diameter to detect findings of increased intracranial pressure in adult head injury patients. Ann Emerg Med 2007, 49(4):508-514.

3. Frumin E, Schlang J, Wiechmann W, Hata S, Rosen S, Anderson C, et al: Prospective analysis of single operator sonographic optic nerve sheath diameter measurement for diagnosis of elevated intracranial pressure. West J Emerg Med 2014, 15(2):217-220.

doi:10.1186/2197-425X-3-S1-A488

Cite this article as: Abdalla et al.: Value of ultrasonographic optic nerve sheath diameter in assessing increased intracranial pressure in patients with moderate to severe traumatic brain injury. Intensive Care Medicine Experimental 2015 3(Suppl 1):A488.

\section{Submit your manuscript to a SpringerOpen ${ }^{\circ}$ journal and benefit from:}

- Convenient online submission

- Rigorous peer review

- Immediate publication on acceptance

- Open access: articles freely available online

- High visibility within the field

- Retaining the copyright to your article

Submit your next manuscript at $>$ springeropen.com 